\title{
Vulvar Cellular Angiofibroma
}

National Cancer Institute

\section{Source}

National Cancer Institute. Vulvar Cellular Angiofibroma. NCI Thesaurus. Code C40327.

A benign neoplasm arising from the fibrous tissue of the vulva. It is characterized by the presence of spindle-shaped fibroblasts, numerous dilated vascular channels, and increased cellularity. 